\title{
Shear Bond Strength of Enamel Surface Treated with Air-abrasive System
}

\author{
Maria Cristina BORSATTO ${ }^{1}$ \\ Alma Blásida Elisaur Benitez CATIRSE 3 \\ Regina Guenka PALMA DIBB ${ }^{2}$ \\ Telma Nunes do NASCIMENTO2 \\ Renata Andréa Salvitti de Sá ROCHA ${ }^{2}$ \\ Silmara Aparecida Milori CORONA ${ }^{2}$ \\ Departments of ${ }^{1}$ Clinical Pediatrics, ${ }^{2}$ Restorative Dentistry and ${ }^{3}$ Dental Materials and Prostheses, \\ Faculty of Dentistry of Ribeirão Preto, University of São Paulo, Ribeirão Preto, SP, Brazil
}

\begin{abstract}
The aim of this study was to evaluate the shear bond strength of a composite resin to dental enamel, using three different surface treatments. Fifteen sound third molars were randomly assigned to three groups. The mesial and distal surfaces were flattened and covered using adhesive tape with a central orifice delimiting the adhesion area $\left(7.07 \mathrm{~mm}^{2}\right)$. Group I, the enamel surface was conditioned with $37 \%$ phosphoric acid for $15 \mathrm{~s}$; group II, the surface was treated using air abrasion with aluminum oxide; group III, the enamel surface was treated using an association of air abrasion with aluminum oxide and $37 \%$ phosphoric acid. The Single Bond (3M) adhesive system was applied and a Teflon matrix was placed and filled with composite resin Z-100 (3M) and light-cured. The shear bond strength test was performed with a universal testing machine. The acid etching technique and air abrasion with aluminum oxide associated with acid etching had the highest shear bond strength values. Data were subjected to statistical analysis using ANOVA and the Tukey test, and no statistically significant difference in shear bond strength was observed between group I (12.49 $\pm 2.85 \mathrm{MPa})$ and group III (12.59 $\pm 2.68 \mathrm{MPa})$. In contrast, both groups had statistically better shear bond strengths compared to group II $(0.29 \pm 0.56 \mathrm{MPa} ; \mathrm{p}<0.05)$. Air abrasion with aluminum oxide does not substitute acid etching. The association of these methods to obtain adequate adhesion to the substrate is necessary.
\end{abstract}

Key Words: aluminum oxide jet, shear bond strength, enamel.

\section{INTRODUCTION}

Knowledge of bonding mechanisms of adhesive restorative materials to the dental substrate, enamel and dentin has led to more favorable clinical results, increasing the longevity of preventive and restorative procedures.

Enamel surface treatment, using the acid etching technique introduced by Buonocore (1), induces microscopic roughness, increasing the available surface area making mechanical adhesion possible. New technologies have since been introduced, providing increased comfort to the patient and professional, as well as enhancing adhesion of restorative materials to the dental structure, decreasing pain sensitivity, and preserving a greater amount of healthy dental structure. These techniques may be accomplished using various systems, such as laser therapy and the application of air abrasion with aluminum oxide, allowing the reduction of the problems of heat generation, vibration and other mechanical stimulation during cavity preparation $(2,3)$.

The use of air abrasion with aluminum oxide basically consists of the application of an abrasive jet with particles of different diameters and may be indicated for the removal of caries and restorative materials, repair of ceramic restorations and surface treatment of enamel and dentin, in addition to the possibility of increasing adhesion of restorative materials to tissues (4-11).

Some studies (12-14) have observed that air abrasive technology has the potential to prepare enamel bonding surfaces similar to those obtained by acid 
etching. In contrast, other studies $(6,15-19)$ evaluating the shear bond strength of the composite resin to enamel, have reported that the application of only air abrasion with aluminum oxide alone does not provide the appropriate surface treatment, demonstrating low values when compared to the conventional acid etching technique. Due to these conflicting results, it is important to conduct a detailed study to better understand the mechanisms of adhesion to enamel when the aluminum oxide jet is used.

Thus the aim of the present study was to evaluate, in vitro, the effects of air abrasion, acid etching, and the combination of both procedures, on the shear bond strength of a composite resin to an enamel surface.

\section{MATERIAL AND METHODS}

Fifteen sound human third molars, extracted within a six-month period and stored in saline solution, were selected and cleaned with a water/pumice slurry in a dental prophylactic cup.

The roots were sectioned $3 \mathrm{~mm}$ below the cementoenamel junction, pulp residues were removed and the mesial and distal surfaces of the crown were delineated using Dura White stones (Shofu Inc., Kyoto, Japan) before standardizing with wet sandpaper of decreasing granulations, \#180 to 600, using a polishing machine (Politriz, Struers A/S, Copenhagen, DK-2610, Denmark). The specimens were washed and stored in distilled water, under refrigeration, for $24 \mathrm{~h}$.

Prophylaxis was carried out with pumice for 20 $\mathrm{s}$. The teeth were washed by air/water spray for $20 \mathrm{~s}$, to remove pumice residues, and dried by air spray for $20 \mathrm{~s}$. Adhesive tape with a central orifice of $3 \mathrm{~mm}$ in diameter was applied to the enamel surface to demarcate the area $(7.07 \mathrm{~mm})$ to be treated.

The teeth were then randomly divided into 3 groups of 10 samples each. Group I: The demarcated area was conditioned with $37 \%$ phosphoric acid gel for $15 \mathrm{~s}$, washed with air/water spray for $20 \mathrm{~s}$, and excess water was removed with absorbent paper, leaving a shiny aspect. Group II: The enamel surface was treated with an air-abrasive system (Kreativ Mach 4.1, New Image do Brazil, São Paulo, Brazil,), with a 0.011-inch nozzle opening, using a $27.5 \mu \mathrm{m}$ aluminum oxide particles stream at $60 \mathrm{psi}$ air pressure with an intensity of 4 $\mathrm{g} / \mathrm{min}$, continuously, for $10 \mathrm{~s}$. This treatment was accomplished at a distance of approximately $2 \mathrm{~mm}$ and at an angle of $45^{\circ}$ to the occlusal surface. The application of the aluminum oxide jet was accomplished inside a closed transparent acrylic box, to avoid particle aspiration by the operator. Group III: The enamel surface was treated with an association of aluminum oxide jet and $37 \%$ phosphoric acid gel. After the use of aluminum oxide, the specimens were washed, dried for $20 \mathrm{~s}$, and etched with $37 \%$ phosphoric acid gel for $15 \mathrm{~s}$.

Two layers of the bonding system (Single Bond, \#18089, 3M Dental Products, St Paul, MN) were applied using a brush saturated with the bonding agent for each layer. The surface was then slightly dried for $5 \mathrm{~s}$ and light cured for $20 \mathrm{~s}$.

After surface treatment, a Teflon matrix of $3 \mathrm{~mm}$ in diameter and $2 \mathrm{~mm}$ in height, was carefully placed on the area previously delimitated and a hybrid lightactivated composite resin (Z-100, \#9CX, 3M) was carefully inserted into the matrix. The composite resin was light-cured for $40 \mathrm{~s}$ (XL 3000, 3M) with an output of $450 \mathrm{~mW} / \mathrm{cm}^{2}$ and the matrix was longitudinally sectioned with a scalpel. The specimens were subsequently stored in distilled water at $37^{\circ} \mathrm{C}$ for $4 \mathrm{~h}$ and before being subjected to a thermocycling regimen of 500 cycles in $5^{\circ} \mathrm{C}$ and $55^{\circ} \mathrm{C}$ waterbaths. Dwell time was 1 min with a 3-s transfer time between baths.

The specimens were included in gypsum, contained in a circular form, which was positioned perpendicular to the base. A space between the composite resin cylinder and the gypsum was carefully maintained. The teeth were then immersed in distilled water and stored at $37^{\circ} \mathrm{C}$ for $14 \mathrm{~h}$. The samples were dried by air spray and submitted to the shear bond strength test (Universal Test Machine, EMIC, Equipamentos e Sistemas de Ensaios Ltda, São José dos Pinhais, PR, Brazil), with load cell of $50 \mathrm{~kg}$ and a cross-head speed of $0.5 \mathrm{~mm} / \mathrm{min}$. The composite resin shear strength was measured in $\mathrm{Kgf}$ and converted to $\mathrm{MPa}$.

The data were submitted to analysis of variance $(\mathrm{p}<0.001)$ and Tukey's test was used to detect differences in means $(\mathrm{p}<0.05)$.

\section{RESULTS}

The analysis of the shear bond strength data showed that group I (37\% phosphoric acid; $12.49 \pm$ $2.84 \mathrm{MPa}$ ) was statistically similar to group III (air abrasion aluminum oxide + phosphoric acid; $12.59 \pm$ $2.68 \mathrm{MPa}$ ) and both groups presented superior results 
when compared to group II (aluminum oxide jet; $0.29 \pm$ $0.56 \mathrm{MPa})(\mathrm{p}<0.05)$.

\section{DISCUSSION}

The results of the present study demonstrated that the application of an aluminum oxide jet in association with the acid conditioning of the enamel presented shear bond strength resistance values statistically similar to those obtained by acid conditioning. Both methods presented better results than the aluminum oxide jet used alone, in agreement with other studies (6,15-19). However, conflicting results have also been reported in the literature, (12-14) in which air abrasive technology was shown to prepare enamel bonding surfaces to the standard of those obtained by acid etching.

In the morphological analysis of the enamel surface, Katora et al. (20) observed the presence of superficial irregularities, altering the surface of the enamel when aluminum oxide jet was applied, and Dotty et al. (12) reported that the group conditioned with phosphoric acid presented a honeycomb aspect, with depths of $6 \mu \mathrm{m}$, and the group treated with the aluminum oxide jet presented an irregular pattern with medium depths of 4-15 $\mu \mathrm{m}$, suggesting that the air abrasion technology may potentially prepare the surface of the enamel in a similar manner to acid conditioning. These findings may explain the results of the present study, where the association of the aluminum oxide jet with acid etching demonstrated statistical similarity to acid conditioning.

When the air abrasive system was used alone, similar results to those of Olsen et al. (16) and Mulcahey et al. (17) were obtained. These authors evaluated the shear bond strength of a composite resin to enamel and reported that surface preparation with an aluminum oxide jet results in a significantly lower bond strength than the conventional acid etching technique. Van Waveren Hogervorst et al. (18) observed that, under certain conditions, the enamel loss associated with sandblasting is equal to, or smaller than, that achieved with acid etching, and concluded that air abrasion with aluminum oxide is not an alternative for the acid etching technique.

The aluminum oxide jet can influence the resistance of the shear bond strength of the composite resin to enamel, making the use of acid etching necessary whenever the aluminum oxide jet is used. Canay et al.
(19) analyzed the tensile bond strength of composite resin enamel and observed that the highest tensile strength was obtained with air abrasion followed by acid etching. In spite of the fact that the methodology was different, the results of our study did not show any significant difference between the group that received acid etching and the group that received air abrasion with aluminum oxide followed by acid etching.

Further investigation focusing on the long-term effects of ultrastructural changes observed in enamel substrate treated by the air-abrasive system may lead to an improvement of shear bond strength, as well as to a more widespread applicability of these new technologies in clinical practice.

\section{RESUMO}

Borsatto MC, Catirse ABEB, Palma Dibb RG, do Nascimento TN, Rocha RASS, Corona SAM. Resistência ao cisalhamento na superfície do esmalte tratada com sistema de ar abrasivo. Braz Dent J 2002;13(3):175-178.

O presente estudo tem por objetivo avaliar a resistência ao cisalhamento da resina composta ao esmalte, utilizando três diferentes tratamentos de superfície. Foram utilizados 15 terceiros molares, divididos aleatoriamente em três grupos. As superfícies mesial e distal foram planificadas e cobertas utilizando uma fita adesiva, com um orifício central delimitando a área de adesão $\left(7,07 \mathrm{~mm}^{2}\right)$. No grupo I, a superfície de esmalte foi condicionada com ácido fosfórico a 37\%, durante 15 segundos; no grupo II, a superfície foi tratada utilizando-se do jato de óxido de alumínio; no grupo III, foi utilizada a associação de jato de óxido de alumínio e ácido fosfórico a 37\%. O sistema adesivo foi aplicado e uma matrix de teflon foi colocada e preenchida com resina composta Z-100 (3M) e fotopolimerizada. A resistência ao cisalhamento foi avaliada com a Máquina de Ensaios Universal. Os maiores valores de resistência ao cisalhamento foram obtidos por meio do condicionamento ácido e da associação jato de óxido de alumínio com condicinamento ácido. Os dados obtidos foram submetidos a análise de variância e teste de Tukey, no qual observou-se que não houve diferença estatisticamente significante na resistência ao cisalhamento entre o grupo I - 12,49MPa $( \pm$ $2,85)$ and group III $-12,59 \mathrm{MPa}( \pm 2,68)$ e ambos os grupos apresentaram diferença estatísticamente significante com o grupo II - 0.29MPa $( \pm 0,56)$. Abrasão a ar com óxido de alumínio não substitui o condicionamento ácido, e é necessário a associação destes métodos para obter uma adequada adesão ao substrato.

Unitermos: jato de óxido de alumínio, resistência ao cisalhamento, esmalte.

\section{REFERENCES}

1. Buonocore MG. A simple method of increasing the adhesion of acrylic filling materials to enamel surfaces. J Dent Res 
1955;34:849-853.

2. Peyton FA, Henry EE. The effect of high speed burs, diamond instruments and air abrasion in cutting tooth tissue. J Am Dent Assoc 1954;49:426-435.

3. Black RB. Application and revaluation of air abrasive technique. J Am Dent Assoc 1955;50:408-414.

4. Ellis RW, Latta MA, Westerman GH. Effect of air abrasion and acid etching on sealant retention: an in vitro study. Pediatr Dent 1999;21:316-319.

5. Goldstein RE, Parkins FM. Using air-abrasive technology to diagnose and restore pit and fissure caries. J Am Dent Assoc 1995;126:761-766.

6. Nikaido T, Kataumi M, Burrow M, Inokoshi S, Yamada T, Takatsu T. Bond strengths of resin to enamel and dentin treated with low-pressure air abrasion. Oper Dent 1996;21:218-224.

7. Horiguchi S, Yamada T, Ikonoshi S, Tagami J. Selective caries removal with air-abrasion. Oper Dent 1998;23:236-243.

8. Chan DCN, Summitt JB, García-Godoy F, Hilton TJ, Chung K-

$\mathrm{H}$. Evaluation of different methods for cleaning and preparing occlusal fissures. Oper Dent 1999;24:331-336.

9. Guirguis R, Lee J, Conry J. Microleakage of restorations prepared with air abrasion. Pediatr Dent 1999;21:311-315.

10. Zyskind D, Zyskind K, Hirschfeld Z, Fuks AB. Effect of etching on leakage of sealants placed after air abrasion. Pediatr Dent 1998;20:25-27.

11. Borsatto MC, Corona SAM, Palma Dibb RG, Ramos RP, Pécora JD. Microleakage on enamel/sealant interface after surface treatment with Er:YAG laser and air-abrasion with aluminum oxide. J Clin Laser Med Surg 2001;19:83-87.
12. Dotty WD, Pettey D, Holder R, Philips S. KCP 2000 enamel etching abilities tested. J Dent Res 1994;73:411 (abstract).

13. Laurell KA, Hess JA. Scanning electron micrographic effects of air-abrasion cavity preparation on humam enamel and dentin. Quintessence Int 1995;26:139-144.

14. Keen DS, von Fraunhofer JA, Parkins FM. Air-abrasive "etching”: composite bond strength. J Dent Res 1994;73:131 (abstract).

15. Roeder LB, Berry 3rd EA, You C, Powers JM. Bond strength of composite to air-abraded enamel and dentin. Oper Dent 1995;20:186-190.

16. Olsen ME, Bishara SE, Damon P, Jakobsen JR. Comparison of shear bond strength and surface structure between conventional acid etching and air-abrasion of human enamel. Am J Orthod Dentofacial Orthop 1997;112:502-506.

17. Mulcahey K, Caputo AA, Duperon DF. In vitro bracket bond strength to acid-etched or air-abraded enamel. Pediatr Dent 1999;21:281-284.

18. Van Waveren Hogervorst WL, Feilzer AJ, Prahl-Andersen B. The air-abrasion technique versus the conventional acid-etching technique: A quantification of surface enamel loss and a comparison of shear bond strength. Am J Orthod Dentofacial Orthop, 2000;117:20-26.

19. Canay S, Kocaderelli I, Akça E. The effect of enamel air abrasion on the retention of bonded metallic orthodontic brackets. Am J Orthod Dentofacial Orthop 2000;117:15-19.

20. Katora ME, Jubachi T, Polimus MM. Airbrasive etching of enamel surface. Quintessence Int 1981;12:967-968.

Accepted March 27, 2002 